\title{
A CONTRIBUTION TO THE WOOD ANATOMY OF SOUTH AMERICAN (CHIEFLY SURINAME) RUBIACEAE. II*
}

\section{J. KOEK-NOORMAN}

Botanisch Museum en Herbarium, Utrecht

SUMMAR Y

This paper contains a discussion of the taxonomic subdivisions of the Rubiaceae as proposed by Schumann, Verdcourt, and Bremekamp. Generally speaking, the subdivisions as proposed and delimited by Bremekamp agree best with the characters of the wood structure, as observed by the author. Furthermore a key to the Suriname genera is given.

\section{INTRODUCTION}

In a preceding paper (KOEK-NOORMAN 1969) a general description of the wood of South American Rubiaceae is given. This is compared with data found in the literature.

In the present study the comprehensive systematic classifications given by SCHUMANN (1897), BREMEKAMP (1954, 1966), and VeRdCOURT (1958) arecompared with notes elsewhere in the literature and the results of the present investigation.

Besides a key to the Suriname genera is provided, based on the material studied by the author.

\section{MATERIAL AND METHODS}

The methods are described in the preceding paper. The species studied are listed at the end of the present paper. The illustrations referred to in this study can be found in the preceding paper.

\section{DISCUSSION}

The classifications by Schumann, Verdcourt, and Bremekamp differ in the number and delimitation of subfamilies, tribes and genera. As Verdcourt's and Bremekamp's systems are the most recent ones and as both authors make use of new characters I shall discuss their work especially. The division by Schumann, Verdcourt, and Bremekamp in subfamilies and tribes is as follows:

* Continued from Acta Botanica Neerl. 18: 108-123. 1969 


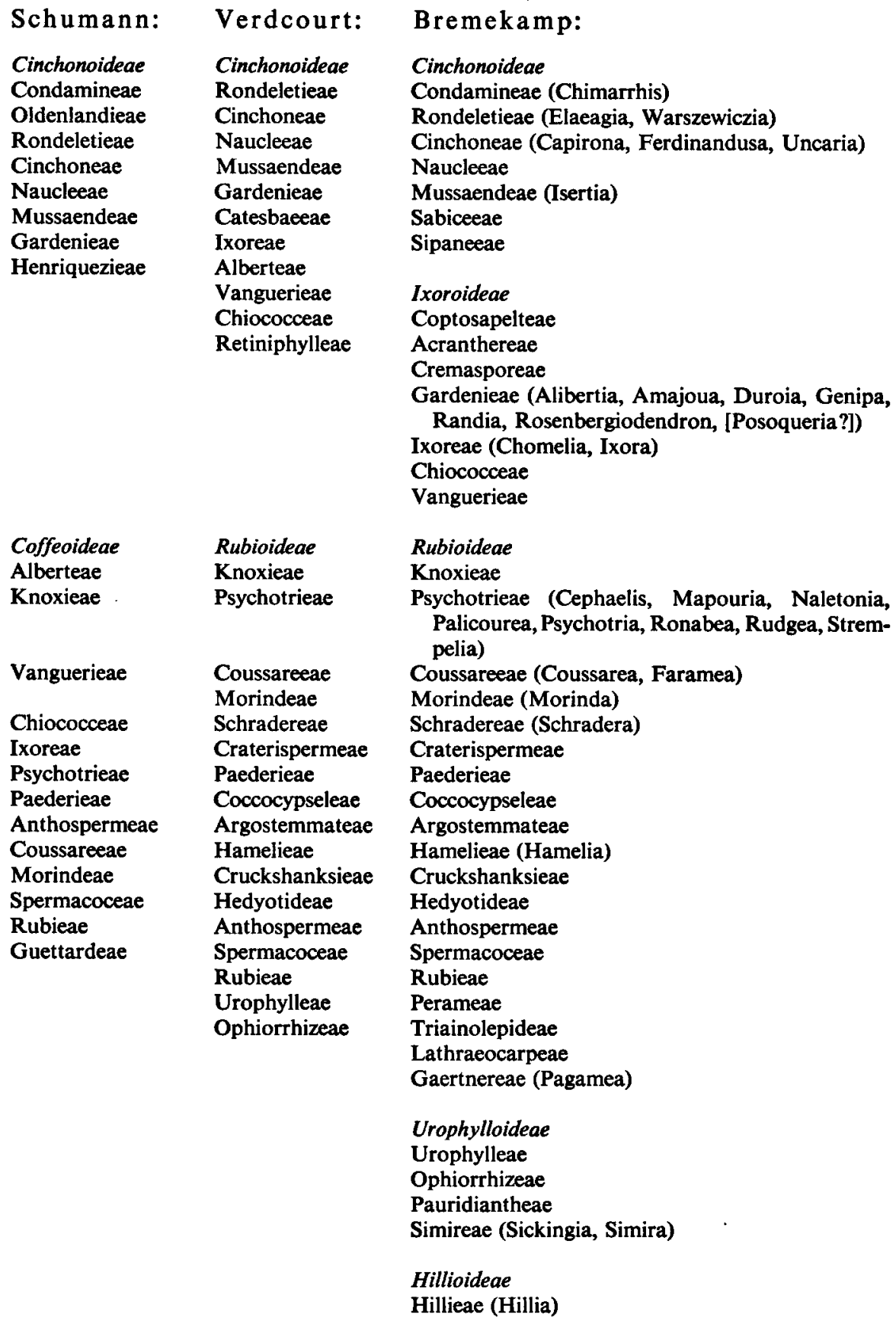


WOOD ANATOMY OF SOUTH AMERICAN RUBIACEAE II

$\begin{array}{ll}\begin{array}{l}\text { Guettardoideae } \\ \text { Guettardeae }\end{array} & \begin{array}{l}\text { Guettardoideae } \\ \text { Guettardeae (Guettarda, Malanea) }\end{array} \\ & \begin{array}{l}\text { Pomazotoideae } \\ \text { Pomazoteae }\end{array} \\ & \begin{array}{l}\text { Gleasonioideae } \\ \text { Gleasonieae }\end{array}\end{array}$

(The genera mentioned between brackets are studied in the recent investigation. To make a comparison between the divisions more easy $I$ listed the tribes in a different arrangement as the authors did).

The subfamily Cinchonoideae, as established by Schumann and Verdcourt, is divided by Bremekamp in Cinchonoideae and Ixoroideae.

\subsection{Subfamily Cinchonoideae:}

Bremekamp divided the tribe Rondeletiae (in the sense Verdcourt intended) in the Condamineae and Rondeletieae, as Schumann did.

Available were wood samples of Chimarrhis longistipulata, Chimarrhis turbinata (Condamineae), Elaeagia maguirei, and Warszewiczia coccinea (Rondeletieae).

Condamineae. Schumann was not sure whether Chimarrhis turbinata was rightly placed in this genus. Ducke (1922) referred it to a new genus, viz. Pseudochimarrhis. According to BREMEKAMP (1932) and STEYERMARK (1965) Chimarrhis and Pseudochimarrhis are not separable. ReCord \& Hess (1944) report that the wood of Pseudochimarrhis barbata Ducke is similar in every respect, to the wood of Chimarrhis. Actually, the wood of Chimarrhis turbinata greatly resembles Chimarrhis longistipulata, the place of which is not in doubt. They differ only in minor features.

Rondeletieae. Elaeagia maguirei and Warszewiczia coccinea, the two species of the Rondeletieae examined, also resemble each other much in their wood structures.

However, there is a clear difference between the investigated samples of the Rondeletieae and of the Condamineae. In the Condamineae the parenchyma is narrowly vasicentric, in the Rondeletieae it is lacking; the Condamineae have 6-12 vessels per sq. $\mathrm{mm}$, which are up to $150 \mu$ wide, in the Rondeletieae the number of vessels is about 40 per sq. $\mathrm{mm}$, their width not over $90 \mu$; the upright ray dells are up to $50 \mu$ and $80 \mu$ respectively; furthermore most Rondeletieae show the combination of over 4-seriate rays of great height and sheath cells (see Koek-Noorman 1969) in contrast to the Condamineae which have no sheath cells or have no broad rays.

Summarizing we may say that the Rondeletieae as far as studied resemble the Rubioideae, whereas the Condamineae as represented by Chimarrhis longisti- 
pulata and Chimarrhis turbinata agree more with our material of the Cinchoneae. This seems to be consistent with the opinion of Bremekamp, when he considers the Condamineae and Rondeletieae to be two distinct tribes.

Simira Aubl. (= Sickingia Willd.), another genus placed in the Rondeletieae by earlier authors, fits in well with the Urophylloideae according to BREMEKAMP (1954). However, as far as wood characters are concerned Elaeagia and Simira agree very well, whereas Simira differs from the structure of Urophyllum as judged from in the descriptions of the latter genus by JANSSONIUS (1926; see p. 387).

Other genera placed in the Urophylloideae by Bremekamp were not studied.

Cinchoneae. Next to Capirona and Ferdinandusa, placed by earlier authors in the tribe of Cinchoneae too, Bremekamp referred Uncaria, until then classed in the Naucleeae, to the Cinchoneae. Ferdinandusa rudgeoides and Capirona surinamensis are fairly similar: Capirona has some vessels in radial pairs, Ferdinandusa has many vessels in small clusters, but they are alike in the structure of the rays, the inconspicuously vestured intervascular pits, the libriform fibres and the very scarce paratracheal parenchyma.

The description of Cinchona sp. by JANSSONIUS (1926) does differ; the material, however, was poor and not identified up to the species. Therefore this material is perhaps not quite reliable. Further investigations in this genus will be needed.

Uncaria guianensis and U.africana (Uw 9464) has many solitary vessels, some in radial pairs, the rays are smaller than those of Capirona and Ferdinandusa, the fibres are non-septate with large bordered pits on radial and tangential walls, and the parenchyma is diffuse.

Naucleeae. I did not study any other representatives of the Naucleeae but descriptions and illustrations of species of Nauclea and other genera belonging to this tribe (JANSSONIUS 1926; NORMAND 1960) resemble Uncaria guianensis in the distribution of the vessels, the structure of the rays, the presence of fibre tracheids and the diffuse parenchyma.

Mussaendeae. Isertia, belonging to the tribe of Mussaendeae, resembles the species of the Ixoreae and Gardenieae studied and Posoqueria (of uncertain position, see p. 381). Curiously Isertia is the only genus of the Cinchonoideae studied which has fibre tracheids, just like the Ixoroideae.

Bremekamp excluded a large number of genera from the Mussaendeae, among others Schradera (transferred to a tribe of its own in the Rubioideae, see p. 385), Tammsia, Pentagonia, Hippotis and Sommeria. The systematic position of the last four genera is uncertain. Of these genera no wood samples were available.

According to Metcalfe \& Chalk (1950) Hippotis and Pentagonia possess libriform fibres. This feature supports Bremekamp's opinion that these genera do not belong in the same tribe with Isertia.

The Sipaneeae and Sabiceeae include only herbaceous genera. 


\subsection{Subfamily Ixoroideae:}

Two tribes were represented, the Gardenieae and Ixoreae (The other tribes are entirely herbaceous or they occur in the Old World, except for the Chiococceae, including shrubs of Central America and the West Indian Isles).

Gardenieae. Many wood samples of the Gardenieae were available, viz. of the genera Alibertia, Amajoua, Duroia, Genipa, Randia and Rosenbergiodendron.

The most samples agree rather well. They show a moderate variation in characteristics of the parenchyma distribution (diffuse, in short or long bands), the diameter and number of the vessels, the width of the rays, etc.

The libriform fibres, the long, not interrupted parenchyma bands and the small and numerous vessels in Alibertia myrciifolia do not fit in with the features of Alibertia edulis nor with the other genera of this tribe studied. Because of these great differences it seems necessary to study this species in more detail in order to decide if it is rightly placed in this genus.

The position of Posoqueria, placed in the Gardenieae by VerdCoURT (1958) and STEYERMARK (1967), it doubtful in Bremekamp's opinion, the pollination mechanism amongst others being different from those of other genera in this tribe. Posoqueria possesses libriform fibres, contrary to most Gardenieae, which supports the idea of Bremekamp.

Ixoreae. Chomelia and Ixora, belonging to the Ixoreae according to Bremekamp, differ in many characteristics. Chomelia resembles many species of the Guettardeae because of the libriform fibres, the structure of the rays and the vessels in radial multiples (table 1). This fits in with the view of STEYeRMARK (1967), who places Chomelia in the Guettardeae. From the material investigated it is not possible to distinguish Ixora from the Gardenieae by the structure of the wood. JANSSONIUS (1926) notes from his study of different genera the same about these two tribes. Using the classification of SchumanN (1897) and BeNTHAM \& HOOKER (1873), in which the Gardenieae and Ixoreae are placed in different subfamilies, he remarks that a classification based upon anatomical characteristics can be quite different from a division based upon other systematic features.

The Vanguerieae classified in the Coffeoideae by Schumann (1897) seem to be rightly placed in the Ixoroideae by Bremekamp, because of the presence of fibre tracheids (JANSSONIUS 1926). No material was studied in the present investigation.

Hamelia, often placed in the Gardenieae (SchumanN 1897) is classified in a separate tribe in the Rubioideae by Bremekamp (see p. 387).

The Retiniphylleae, belonging to the Cinchonoideae according to VeRDCOURT (1958), have not been classified by BREMEKAMP (1966), who is of the opinion that a detailed study is necessary before a decision can be made about the right position of Retiniphyllum (see p. 388).

The Henriquezieae are changed from tribe to family: Henriqueziaceae (BREMEKAMP 1956; see p. 389). 


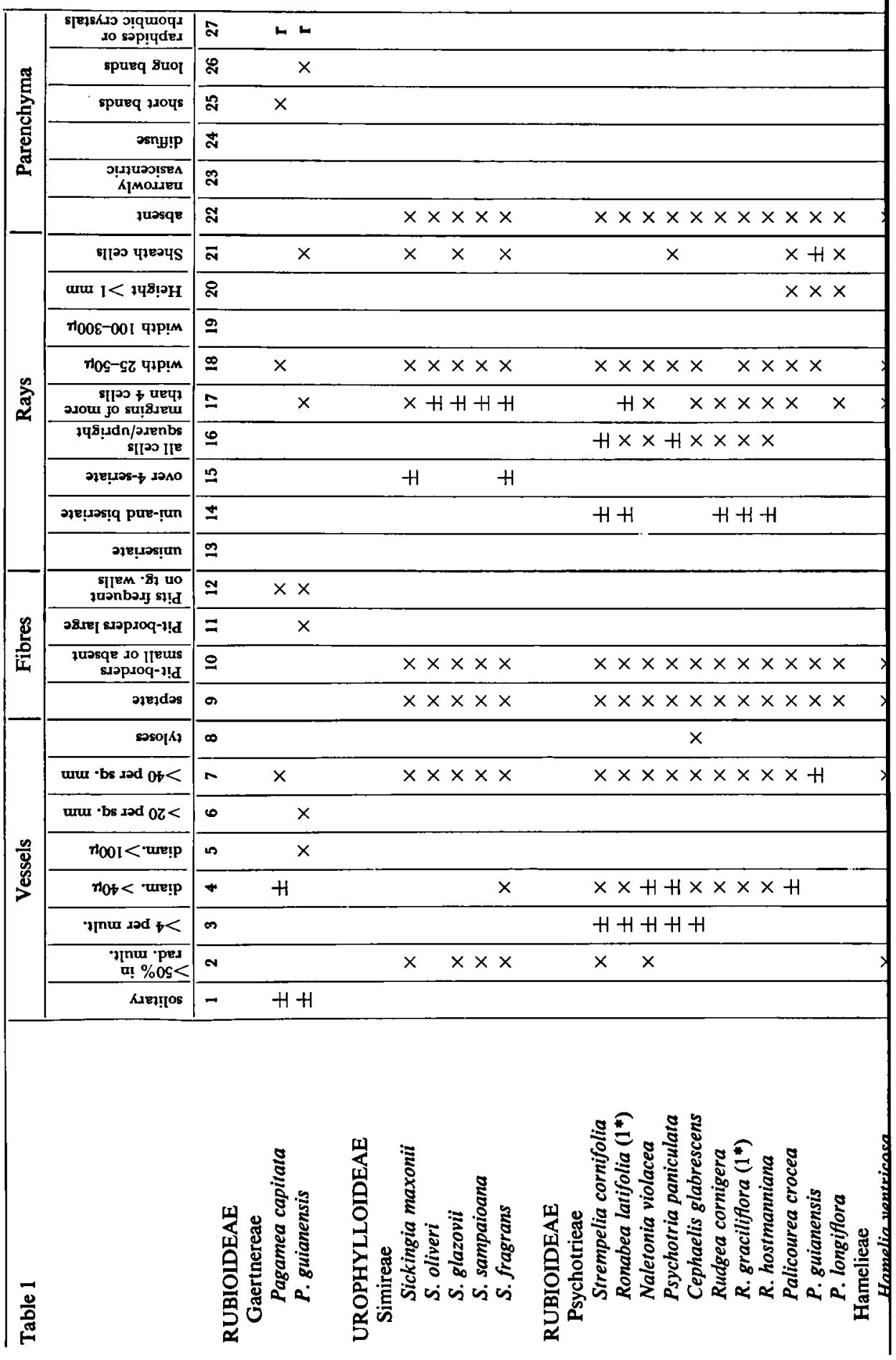




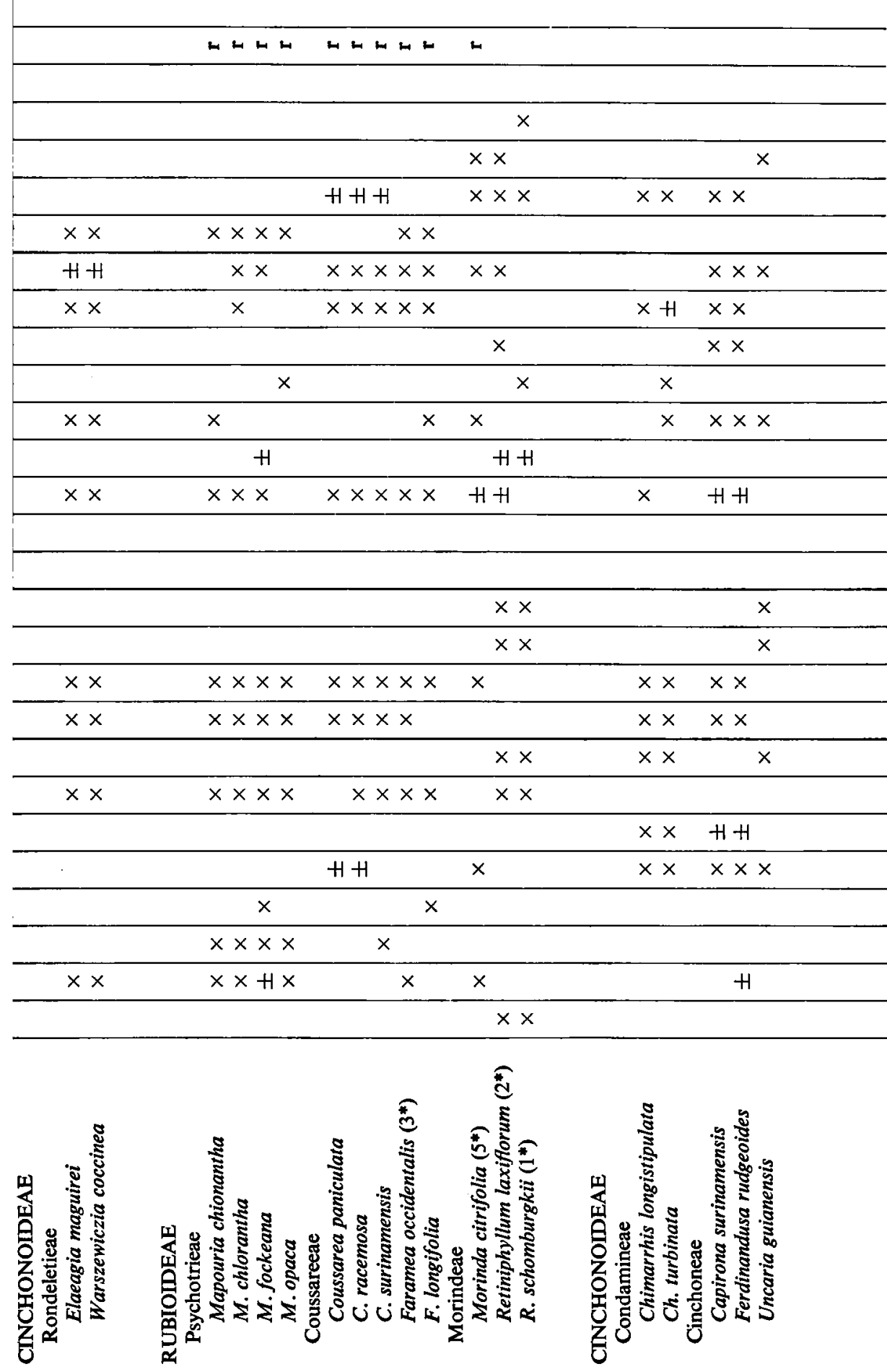




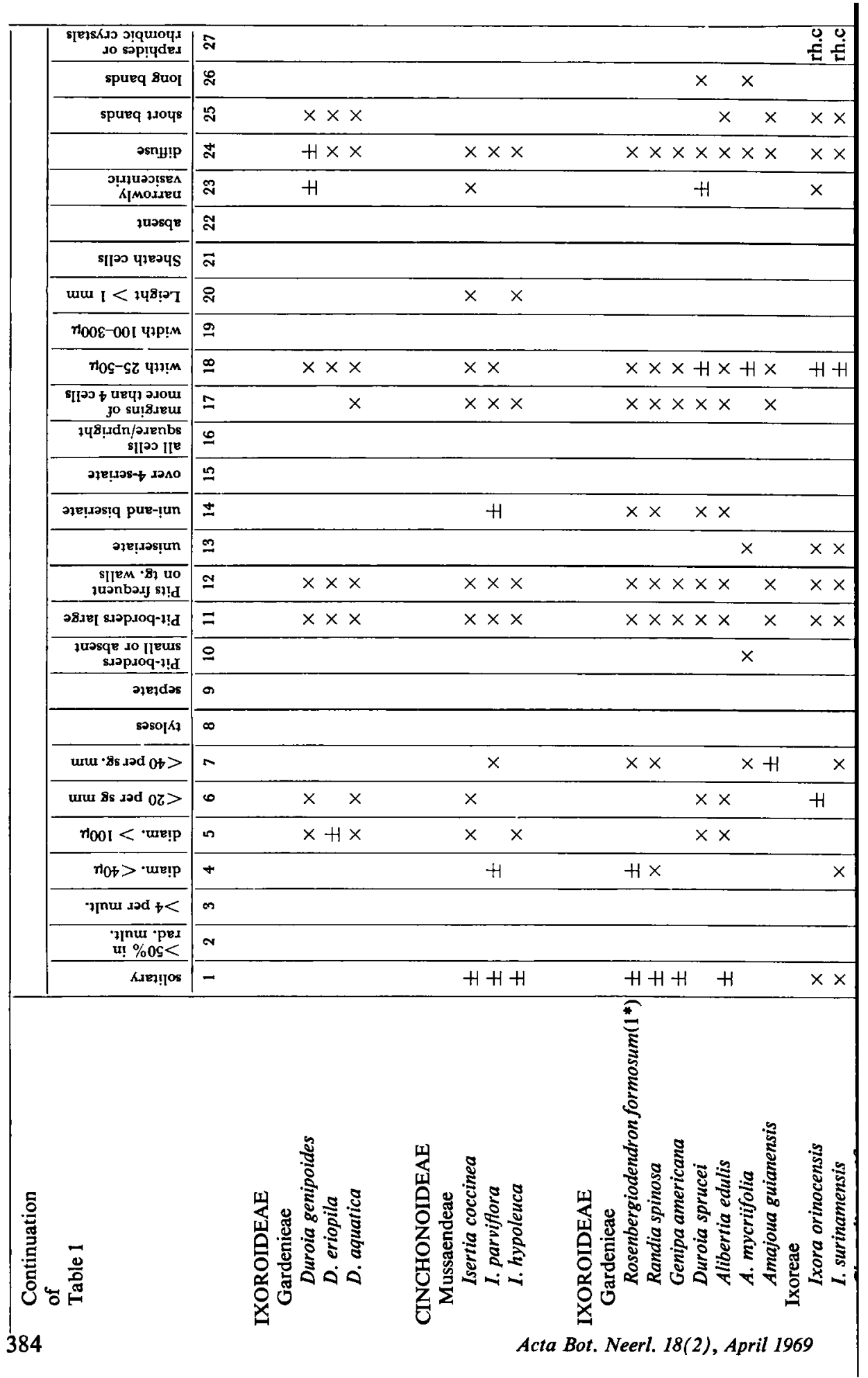


The subfamily of Rubioideae as circumscribed by VERDCOURT (1958) is divided by BREMEKAMP $(1940,1966)$ in the Urophylloideae and Rubioideae.

\subsection{Subfamily Rubioideae:}

Bremekamp considers the presence of raphides in any part of the plant essential for all genera of the Rubioideae; on the other side, all genera possessing raphides belong in this subfamily according to him (the only exception being Hillia which is placed in a subfamily of its own: Hillioideae). Indeed, in many genera studied raphides are present in ray or parenchyma cells.

The tribes of the Rubioideae represented were the Psychotrieae, Coussareeae, Morindeae, Schradereae, Gaertnereae, and Hamelieae.

Psychotrieae. The wood of the genera of the tribe Psychotrieae is very similar. Mapouria is recognizable by the radial vessel multiples of more than 4 cells, and the frequency of the raphides in the ray cells. Palicourea is exceptional in that it has many procumbent ray cells. Cephaelis, Naletonia, Psychotria, Ronabea, Rudgea, and Strempelia can hardly be told apart, as is apparent from the key. The rays differ slightly in number, but these differences do not permit diagnostic conclusions, neither can one divide the genera on the small differences in fibre length and vessel diameter. Raphides in the ray cells of species of Psychotria as mentioned by JANSSONIUS (1926) and Hess (1936) were not present in the studied sample of Psychotria paniculata.

Coussareeae. The woods of the genera Coussarea and Faramea of the Coussareeae are as difficult to distinguish from each other as the woods of the Psychotrieae are. They stand apart from the other Rubioideae by their scanty vasicentric parenchyma, also mentioned by Metcalfe \& CHALK (1950). Raphides are numerous in both genera.

Morindeae. Of the Morindeae two samples of Morinda citrifolia were studied. Although one sample was taken from a branch, with a diameter of $1.5 \mathrm{~cm}$, and the other specimen was $10 \mathrm{~cm}$ wide, their wood structures are much alike and they well correspond with the description by JANSSONIUS (1926). Because of the numerous raphides Bremekamp and Verdcourt refer this genus to the Rubioideae. Raphides do occur in the axial parenchyma. The abundant apotracheal and paratracheal parenchyma is very exceptional in this subfamily, Morinda citrifolia being the only species of the material studied in which it occurs. SolEREDER (1885) mentions this feature for Morinda royoc; NoRMAND (1960) describes Morinda geminata and Morinda lucida with numerous 4-6-seriate parenchyma bands, but remarks, that this feature is not constant within the whole genus.

Schradereae. The tribe of Schradereae was represented by a sample of Schradera rotundata, collected in Colombia. Because of the non-lignified axial and ray parenchyma, the large oval fibre pits $(12-15 \mu)$ and the large intervascular pits 
$(12 \mu)$, Schradera rotundata does not very well resemble the other Rubiaceae studied. However, the libriform fibres and the frequent occurrence of raphides in the apotracheal parenchyma suggest affinity to the Rubioideae. For these very reasons Schradera is not related to Isertia, with which genus Schumann (1897) placed it in the Mussaendeae.

Gaertnereae. The Gaertnereae include Pagamea and Gaertnera, of which Pagamea is represented in tropical America. On account of the almost entirely superior ovary both genera were often placed in the Loganiaceae and they are also treated under that family by RECORD \& Hess (1944) and by NoRmand (1960). SOLEREDER (1885) considers both genera to belong to the Rubiaceae on account of the anatomical structure. BREMEKAMP (1966) concluded from the presence of raphides and a number of morphological characteristics that Pagamea and Gaertnera are closest to the Psychotrieae. Indeed the presence of raphides in Pagamea fits in with the Rubioideae, whereas raphides are lacking in the Loganiaceae. The parenchyma bands in Pagamea indicate the isolated place in the Rubioideae because parenchyma bands are rare in this subfamily (Morin$d a)$, though they are found in other Rubiaceae.

Hamelieae. The Hamelieae, represented by Hamelia ventricosa, collected in Jamaica, fit very well in with the Rubioideae as regards the libriform fibres, the absence of parenchyma and the number and diameter of the vessels, whereas the Gardenieae, in which tribe Hamelia was placed by previous authors (SCHUMANN 1897), possess fibre tracheids, and parenchyma in short or long bands. The tribes Craterispermeae, Coccocypseleae, Argostemmatideae, Cruckshanksieae, Anthospermeae, Spermacoceae, Rubieae, Paederieae, Knoxieae, Perameae, Triainolepideae, and Lathraeocarpeae were excluded from the present investigation, being either absent from tropical South America or non-woody. Of Hindsia, belonging to the Hedyotideae (small shrubs) no wood sample was available.

\subsection{Subfamily Urophylloideae:}

The Urophylloideae include four tribes of which only the Simireae with the sole genus Simira, are woody plants of tropical South America. Although this genus - congeneric with Sickingia Willd. (BREMEKAMP 1954) - has an isolated position within the family, Bremekamp places it in this subfamily, but in order to decide whether it has correctly been referred to the Urophylloideae or not, it will have to be studied in more detail (BREMEKamp 1966). In Schumann's division (1897) of the Rubiaceae it was placed in the Rondeletieae (subfamily Cinchonoideae), and the same was done by VerDCOURT, who combined the Condamineae and Rondeletieae to the Condamineae (1958). Of the Rondeletieae the only specimens available were Elaeagia maguirei and Warszewiczia coccinea. As stated before (p. 380) the structure of these species is so much alike to the structure of members of the Rubioideae that from the investigated samples no suggestions about the correct place of Simira in one tribe or the other can be given. 
The species of Simira studied do not square very well with the description of Urophyllum longifolium (SOLEREDER 1885) and Urophyllum glabrum and other species (JANSSONIUS 1926) as regards the structure of the rays, the presence of diffuse parenchyma and fibre tracheids.

The description of Urophyllum does not fit in with the Rubioideae studied (in which subfamily Urophyllum is placed by Verdcourt) because of the presence of fibre tracheids and the structure of the rays. Perhaps Urophyllum is more or less alike to Retiniphyllum or to Isertia (which has smaller parts of procumbent ray cells, and which does not have fused rays). Isertia belongs to the Mussaendeae, to which tribe Urophyllum is also assigned by Schumann.

\subsection{Subfamily Hillioideae:}

Hillia, included by Schumann in the Cinchoneae (Cinchonoideae) was considered by Bremekamp and Verdcourt to be related to the Rubioideae because of the presence of raphides. Later, however, BREMEKAMP (1966) placed it in a separate subfamily Hillioideae. Although raphides are present the wood anatomy supports this concept because of the very large diameter of the vessels (up to $500 \mu$ ), the oval intervascular pits, $15-18 \mu \mathrm{long}$, and the wide and numerous rays which occupy about one half of the surface in tangential sections, and the broad confluent parenchyma bands.

\subsection{Subfamily Guettardoideae:}

About the subfamily Guettardoideae Verdcourt and Bremekamp are of the same opinion. It consists of one tribe: Guettardeae, to which belong amongst others Guettarda and Malanea. Except for Guettarda acreana the investigated species of Guettarda agree rather well in the structure of the rays, the distribution, number and diameter of the vessels, the septate libriform fibres and the absence of parenchyma. Guettarda acreana Krause, identical with Antirrhoa surinamensis Brem., differs in the presence of small rhombic crystals in ray and parenchyma cells, the narrower (to $25 \mu$ ) and higher multiseriate parts of the rays, the non-septate libriform fibres and the long, 4-5-seriate parenchyma bands.

Chomelia, placed in the Ixoreae by Bremekamp, belongs according to STEYERMARK (1967) in the Guettardeae. Wood anatomically there is more agreement between this tribe and Chomelia than between Chomelia and the Ixoreae (table 1 and p. 381).

Further study of the wood anatomy and pollen morphology of this subfamily could be of interest, for instance to decide whether Guettarda acreana is related to other representatives of this subfamily or not.

\subsection{Genera of a doubtful position}

The position of Retiniphyllum, placed in a separate tribe by VERDCOURT (1958), Steyermark (1965), and also by BREMEKAMP (1934), is not discussed by the last mentioned author in his most recent publication (1966). Only small branches of Retiniphyllum laxiflorum and Retiniphyllum schomburgkii were available for in- 
vestigation, material, on which an opinion hardly can be based because of a possible discrepancy between juvenile and mature wood. However, judging from this material the structure fits in better with the Cinchonoideae and Ixoroideae than with the Rubioideae. Verdcourt believes that they are to be placed near the Ixoreae. (In a personal communication Bremekamp accepted this idea.)

Schuman too accepted the Henriquezieae, introduced by HoOKER (1873) for referring the genera Henriquezia and Platicarpum as a tribe within the Rubiaceae. BREMEKAMP (1956) who considers both genera to be related, but denies close relationship with the Rubiaceae, created the family of Henriqueziaceae.

Wood of Henriquezia jenmani was available. It differs from the Rubiaceae studied in having more distinctly vestured intervascular pits, very heterocellular uniseriate rays: rows of procumbent cells alternating with rows of upright cells, and aliform parenchyma.

STEYERMARK (1964) mentions that Henriquezia jenmani differs in a number of morphologic features from the other species, which form a close unit and have about the same geographic distribution, whereas Henriquezia jenmani occurs in British Guiana as the sole species of this genus. Further investigations are necessary, before a decision based upon wood anatomy can be made.

Of the subfamily Pomazotoideae no representatives are known from tropical America, consequently it was excluded from this investigation.

The Gleasonioideae include one genus, Gleasonia, occurring in Venezuela and Brazil, of which no samples were available.

In this investigation the author investigated only few species of most tribes and subfamilies. The plan is to expand the preliminary studies with additional material.

\section{KEY TO THE SURINAME GENERA:}

1. a. Raphides present (Hillioideae, Rubioideae) . . . . . . . . . . . . .2

b. Raphides absent . . . . . . . . . . . . . . . . . . . .6

2. a. Parenchyma in broad bands; diameter of the vessels to $500 \mu$; pits between rays and vessels irregularly shaped, apertures oval, $12-15 \mu$ long

. . . . . . . . . . . . . . . . Hillia tubiflora

b. Parenchyma absent, diffuse, or in short or long bands; diameter of the vessels smaller; pits between rays and vessels nearly always similar to the intervascular pitting .. . . . . . . . . . . . . . . 3

3. a. Parenchyma lacking; more than $50 \%$ of the vessels in radial multiples, these often of more than 4 cells; wood reddish brown . . . . . Mapouria

b. Parenchyma absent or present; commonly less than $50 \%$ of the vessels in radial multiples, multiples of more than 4 cells scarce or absent $\quad . .4$ 
4. a. Parenchyma in very scarce paratracheal strands or absent

. Coussarea, Faramea

b. Paratracheal parenchyma abundant; apotracheal parenchyma diffuse or in short of long bands or absent . . . . . . . . . . . . . .5

5. a. Diffuse and paratracheal parenchyma abundant; rays 4-7-seriate . . .

. . . . . . . . . . . . . . . . . . . Morinda

b. Parenchyma in short or long bands; fibre pits with large borders, frequent on radial and tangential walls . . . . . . . . . . .Pagamea

6. a. Multiseriate rays composed of upright/square cells, of ten with one or two wings of upright cells; diameter of the vessels to $65 \mu$, mostly less than $40 \mu$; parenchyma absent; fibres septate, pits without or with small borders (Psychotrieae; see also Retiniphyllum) . . . . . . . . . . . . . .7

b. Multiseriate rays composed of procumbent and square/upright cells; diameter of the vessels to $100 \mu$; parenchyma absent or present; fibres septate or non-septate . . . . . . . . . . . . . . . .8

7. a. Colour yellowish brown; many sheath cells present; diameter of the vessels $40-60 \mu \quad$. . . . . . . . . . . . . . . Psychotria

b. Colour brown; sheath cells absent; diameter of the vessels less than $40 \mu$ Cephaelis, Naletonia, Ronabea, Rudgea, Strempelia

8. a. Parenchyma absent; sheath cells mostly present; fibres septate with pits with very small borders . . . . . . . . . . . . . . 9

b. Parenchyma diffuse, paratracheal or in bands . . . . . . . . . . 11

9. a. Rays 4-7-seriate, to $2 \mathrm{~mm}$ ( 100 cells) high; uniseriate wings composed of more than 4 rows; sheath cells scarce; more than $50 \%$ of the vessels in radial multiples, more than 40 vessels per sq. $\mathrm{mm}$; . . . Elaegia

b. Rays 2-4-seriate . . . . . . . . . . . . . . . . . . . . 10

10. a. Pluriseriate parts of the rays to over $1 \mathrm{~mm}$ high, sheath cells present; less than $50 \%$ of the vessels in radial multiples, the diameter to $100 \mu$. .

b. Pluriseriate parts of the rays to $500 \mu$ high, sheath cells absent; more than $50 \%$ of the vessels in radial multiples, the diameter to $45 \mu$

11. a. Rays uniseriate or for a very short length biseriate . . . . . . . .12

b. Rays pluriseriate, often over 4-seriate rays present . . . . . . . . .13

12. a. Vessels nearly all solitary; fibres non-septate, pits with large borders; parenchyma diffuse and in short bands; rhombic crystals present in the parenchyma .. . . . . . . . . . . . . . . Ixora

b. Vessels partly in radial multiples; parenchyma in long and short bands; crystals absent . . . . . . . . . . . . . . . Alibertia

13. a. Rays to $130 \mu$ ( 5 cells) wide, to more than $3,5 \mathrm{~mm}$ high; parenchyma narrowly vasicentric; fibres septate with pits with small borders; less than 20 vessels per sq. $\mathrm{mm}$, the diameter $100-160 \mu$; many vessels in small clusters . . . . . . . . . . . Capirona, Ferdinandusa

b. Rays mostly less than $50 \mu$ wide (see however Retiniphyllum laxiflorum: to $130 \mu$ wide) . . . . . . . . . . . . . . . . . 14 
14. a. Vessels solitary, with tyloses; fibres non-septate, the pits on radial and tangential walls with large borders; rays composed of square/upright cells; parenchyma narrowly vasicentric and diffuse or in short bands

Retiniphyllum

b. Vessels solitary and in (sometimes few) radial multiples; rays composed of procumbent and square/upright cells . . . . . . . . . 15

15. a. Fibres septate; parenchyma narrowly vasicentric; the diameter of the vessels more than $100 \mu$, less than 20 vessels per sq. mm; wood reddish brown .. . . . . . . . . . . . . Chimarrhis

b. Fibres non-septate . . . . . . . . . . . . . . . . 16

16. a. Diameter of the vessels to $250 \mu$; fibre pits with large borders

17. a. Fibres with large bordered pits, pits rather frequent on radial and tangential walls ................ . . . . . 18

b. Fibre pits without or with small borders, often scarce on tangential walls

.. . . . . . . . . . . . . . . . . 19

18. a. Parenchyma in long or short bands . . . . . . Amajoua, Duroia

b. Parenchyma diffuse and sometimes narrowly paratracheal; most vessels solitary . . . . . Isertia, Genipa, Randia, Rosenbergiodendron

19. a. Some radial multiples consisting of more than 4 vessels; rays 2-3-seriate; rhombic crystals in parenchyma; wood reddish brown

Guettarda acreana

b. Hardly any radial multiples of more than 4 vessels present; rays mostly 1-2-seriate . . . . . . . . . . Chomelia, Posoqueria

\section{MATERIAL STUDIED}

Alibertia edulis (L. Rich.) A. Rich.: Suriname- Uw 10927 (Florschütz \& Maas 2346, Kabalebo airstrip; diam. $3.5 \mathrm{~cm}$ ); Brazil - Uw 9062 (Belem 51813, Rio Araguari, Amapa; diam. unknown, over $10 \mathrm{~cm}$ ).

Alibertia myrciifolia K. Schum.: Suriname- Uw 6652 (Heyligers 469, Suriname; tree, $11 \mathrm{~m}$ high, diam. $10 \mathrm{~cm}$ ); Brazil - Uw 8087 (Krukoff 6993, Amazonas; branch, diam. $3.5 \mathrm{~cm}$ ).

Amajoua guianensis Aubl.: Suriname - Uw 1414 (Lanjouw \& Lindeman 1186, between Wiawia-bank and Grote Zwiebelzwamp; tree, $7 \mathrm{~m}$ high, diam. $6 \mathrm{~cm}$ ); Uw 1780 (Lanjouw \& Lindeman 2480, Nassau Mountains; tree, $8 \mathrm{~m}$ high, diam. $7.5 \mathrm{~cm}$ ); Uw 2874 (Lindeman 3900, Mapane kreek area; tree, $12 \mathrm{~m}$ high, diam. $5.5 \mathrm{~cm}$ ); Uw 2970 (Mennega 434, Tanjimama R.; tree, $5 \mathrm{~m}$ high, diam. $5 \mathrm{~cm}$ ); British Guiana - Uw 1075 (Forest Dept. 2609); Venezuela - Uw 11779 (Breteler 3804, Rio Grande o Toro; tree, $8 \mathrm{~m}$ high, diam. $8 \mathrm{~cm}$ ); Brazil - Uw 6337 (Reitz \& Klein 14438, Santa Catarina; $8 \mathrm{~m}$ high, diam. $5 \mathrm{~cm}$ ); Uw 7882 (Krukoff 6699, Amazonas; tree, $12 \mathrm{~m}$ high, diam. unknown).

Capirona surinamensis Brem.: Suriname - Uw 172 (Stahel 172, Zanderij I); Uw 2426 (Lindeman 3681, Mapane Kreek area; tree, $15 \mathrm{~m}$ high, diam. $7.5 \mathrm{~cm}$ ); Uw 6861 (Schulz 8583, Suriname R., Jodensavanne; tree, $30 \mathrm{~m}$ high, diam. $45 \mathrm{~cm}$ ).

Cephaelis glabrescens (Muell. Arg.) Standley: Suriname - Uw 3248 (Lindeman 4724, Mapane Kreek area; shrub, $5.5 \mathrm{~m}$ high, diam. $3 \mathrm{~cm}$ ); Uw 3547 (Lindeman 4674, Mapane Kreek area; shrub, $4 \mathrm{~m}$ high, diam. $2 \mathrm{~cm}$ ).

Chimarrhis longistipulata Brem.: Suriname - Uw 207 (Pulle 379, Kabalebo R., Avanovero falls; diam. unknown, over $12 \mathrm{~cm}$ ). 
Chimarrhis turbinata DC.: Suriname - Uw 261 (Stahel 261, Zanderij I); Uw 1935 (Lanjouw \& Lindeman 2810, Nassau Mountains; tree, $20 \mathrm{~m}$ high, diam. $17 \mathrm{~cm}$ ); Uw 4951 (Schulz 7289, Mapane Kreek area; diam. $70 \mathrm{~cm}$ ); Uw 10844 (v. Donselaar 1297, Brokopondo; tree, $20 \mathrm{~m}$ high, diam. $24 \mathrm{~cm}$ ); Uw 10846 (v. Donselaar 1324, Brokopondo; tree, $20 \mathrm{~m}$ high, diam. $10 \mathrm{~cm}$ ); French Guiana - Uw 5751 (BAFOG 1262, Cayenne).

Chomelia tenuiflora Bth.: Suriname - Uw 378 (Stahel 378, Wayombo).

Coussarea paniculata (Vahl) Standley: Suriname - Uw 2303 (Lindeman 3528, Suriname R., Jodensavanne; tree, diam. $15 \mathrm{~cm}$ ); Uw 2338 (Lindeman 3570, Suriname R., Jodensavanne; tree, $11 \mathrm{~m}$ high, diam. $18 \mathrm{~cm}$ ); Uw 4550 (Lindeman 6731, Mapane Kreek area; diam. $14 \mathrm{~cm}$ ); Uw 4756 (Lindeman 7110, Wayombo R.; diam. $16 \mathrm{~cm}$ ); British Guiana-Uw 1077 (Forest Dept. 3810).

Coussarea racemosa A. Rich.: Suriname - Uw 8565 (Daniels \& Jonker, Emmaketen; tree, $7 \mathrm{~m}$ high, diam. $4 \mathrm{~cm}$ ).

Coussarea surinamensis Brem.: Suriname - Uw 280 (Stahel 280, Saramacca R.); Uw 1164 (Lanjouw \& Lindeman 351, between Moengo Tapoe and Grote Zwiebelzwamp; tree, diam. $10 \mathrm{~cm}$ ); Uw 1167 (Lanjouw \& Lindeman 354, between Moengo Tapoe and Grote Zwiebelzwamp; tree, $8 \mathrm{~m}$ high, diam. $9 \mathrm{~cm}$ ); Uw 1175 (Lanjouw \& Lindeman 362, between Moengo Tapoe and Grote Zwiebelzwamp; tree, diam. $10 \mathrm{~cm}$ ); Uw 2559 (Maguire 24861 $=$ Yale 44276, Coppename R.; tree, $10 \mathrm{~m}$ high, diam. $10 \mathrm{~cm}$ ).

Duroia aquatica (Aubl.) Brem.: Suriname - Uw 1631 (Lanjouw \& Lindeman 2158, Nassau Mountains; treelet, diam. $3.5 \mathrm{~cm}$ ); Uw 2334 (Lindeman 3565, Suriname R., Jodensavanne; tree, $11 \mathrm{~m}$ high, diam. $7 \mathrm{~cm}$ ); Uw 2702 (Lindeman 3710, Mapane Kreek area; tree, diam. $20 \mathrm{~cm}$ ); Uw 11207 (LBB 10782 (Maas), Maratakka R.; tree, $5 \mathrm{~m}$ high, diam. $7 \mathrm{~cm}$ ); French Guiana - Uw 5365 (BAFOG 290 M); Uw 5366 (BAFOG 291 M).

Duroia eriopila L.f.: Suriname - Uw 324 (Stahel 324, Zanderij I, Sectie 0); Uw 351 (Stahel 351, Wayombo); Uw 1328 (Lanjouw \& Lindeman 808, between Moengo Tapoe and Grote Zwiebelzwamp; tree, $8 \mathrm{~m}$ high, diam. $10 \mathrm{~cm}$ ); Uw 5000 (Schulz 7371, Wayombo; tree, diam. $5 \mathrm{~cm}$ ); Uw 11267 (Maas 3267, Maratakka R.; tree, $8 \mathrm{~m}$ high, diam. $4 \mathrm{~cm}$ ); British Guiana - Uw 1078 (Forest Dept. 3179).

Duroia genipoides Hook. f.: Suriname - Uw 1922 (Lanjouw \& Lindeman 2778, Nassau Mountains; tree, $27 \mathrm{~m}$ high, diam. $12 \mathrm{~cm}$ ); Uw 2553 (Maguire 24393 = Yale 44122, Tafelberg; tree, $10 \mathrm{~m}$ high. diam. $15 \mathrm{~cm}$ ); British Guiana - Uw 1079 (Forest Dept. 4038, Moraballi Kreek; tree, $20 \mathrm{~m}$ high, diam. $8 \mathrm{~cm}$ ).

Duroia sprucei Rusby: Suriname - Uw 243 (Stahel 243, Zanderij I); Uw 277 (Stahel 277, Zanderij I).

Elaeagia maguirei Standley: Suriname - Uw 2552 (Maguire 24449 = Yale 44132, Tafelberg; tree, $15 \mathrm{~m}$ high, diam. $30 \mathrm{~cm}$ ).

Faramea longifolia Bth.: Suriname - Uw 2969 (Mennega 433, Tanjimama R.; tree, sample from branch, diam. $4 \times 7 \mathrm{~cm}$ ); Uw 3930 (Lindeman 5772, Mapane Kreek area; tree, $6 \mathrm{~m}$ high, diam. $2.5 \mathrm{~cm}$ ); Uw 3986a (Lindeman 5834a, Rikanau near Moengo; treelet, diam. $2.5 \mathrm{~cm}$ ).

Faramea occidentalis (L.) A. Rich.: Suriname - Uw 3867 (Lindeman 5591, Coppename R.; treelet, diam. $5 \mathrm{~cm}$ ); Uw 4319 (Lindeman 6304, Coppename R.; tree, $8 \mathrm{~m}$ high, diam. $6 \mathrm{~cm}$ ); Uw 8638 (Kramer \& Hekking 2192, Jarikaba Kreek; tree, $6 \mathrm{~m}$ high, diam. $4.5 \mathrm{~cm}$ ); Panama - Uw 7189 (Smithsonian Institution 770).

Ferdinandusa rudgeoides (Bth.) Hook. f.: Suriname - Uw 1933 (Lanjouw \& Lindeman 2807, Nassau Mountains; tree, diam. $15 \mathrm{~cm}$ ); Uw 2551 (Maguire $24879=$ Yale 44284, Saramacca R.; tree, $20 \mathrm{~m}$ high, diam. $30 \mathrm{~cm}$ ); Uw 5449 (Schulz 7990; diam. $10 \mathrm{~cm}$ ).

Genipa americana L.: Suriname - Uw 193 (Stahel 193, Powaka near Carolina); Uw 379 (Stahel 379, Wayombo); Uw 677 (BBS 82, Para R., Osembo); Uw 699 (BBS 105, Saramakka R., Klein Moho); Uw 1345 (Lanjouw \& Lindeman 906, between Moengo Tapoe and Grote Zwiebelzwamp; tree, diam. $17 \mathrm{~cm}$ ); Uw 1387 (Lanjouw \& Lindeman 1104, between Wia-wia-bank and Grote Zwiebelzwamp; tree, diam. $7.5 \mathrm{~cm}$ ); Uw 1555 (Lanjouw \& Lindeman 1806, Tibitisavanne; tree, diam. $12 \mathrm{~cm}$ ); Uw 11614 (B.W. $6230=$ S.O.H. 316, diam. unknown, over $20 \mathrm{~cm}$ ); British Guiana - Uw 1080 (Forest Dept. 753); French 
Guiana - Uw 5772 (BAFOG 1284, Cayenne).

Guettarda acreana Krause: Suriname - Uw 4786 (Helstone 237, Maratakka R.; tree, diam. $9 \mathrm{~cm}$; TYPE of Antirrhoa surinamensis Brem.); Uw 716 (BBS 123, Kabalebo R., Avanovero falls); British Guiana - Uw 1081 (Forest Dept. 2317).

Guettarda elliptica Sw.: Florida - Uw 6305 (Stern \& Brizicky 530 = Yale 51311, Windley's Key; diam. $4 \mathrm{~cm}$ ).

Guettarda pungens Urb.: Dominican Republic - Uw 7279 (Smithsonian Institution 1989; diam. $6 \mathrm{~cm}$ ).

Guettarda scabra (L.) Vent.: Florida - Uw 6172 (Stern \& Brizicky $320=$ Yale 51145, Little Torch Key; diam. $2 \mathrm{~cm}$ ).

Guettarda spruceana Muell. Arg.: Suriname - Uw 4256 (Lindeman 6214, Moengo Tapoe; tree, $12 \mathrm{~m}$ high, diam. $8 \mathrm{~cm}$ ).

Hamelia ventricosa Sw.: Jamaica - Uw 8356 (Smithsonian Institution 6017).

Henriquezia jenmani K. Schum.: British Guiana - Uw 1082 (Forest Dept. 3583).

Hillia tubiflora Cham.: Suriname - Uw 3510 (Lindeman 5237, Mapane Kreek area; epiph.).

Isertia coccinea (Aubl.) Gmel.: Suriname - Uw 1924 (Lanjouw \& Lindeman 2781, Nassau Mountains; tree, $6 \mathrm{~m}$ high, diam. $7 \mathrm{~cm}$ ); Uw 1952 (Lanjouw \& Lindeman 2860, Nassau Mountains; tree, $12 \mathrm{~m}$ high, diam. $9 \mathrm{~cm}$ ); French Guiana - Uw 5358 (BAFOG $283 \mathrm{M}$ ).

Isertia hypoleuca Bth.: Suriname - Uw 2986 (Mennega 513, Kodji Kreek; tree, $11 \mathrm{~m}$ high, diam. $15 \mathrm{~cm}$ ); Uw 6795 (Schulz 8317, Corantyne R.; tree, $14 \mathrm{~m}$ high, diam. $15 \mathrm{~cm}$ ).

Isertia parvifora Vahl.: Suriname - Uw 680 (BBS 85, Para R., Osembo); Uw 1284 (Lanjouw \& Lindeman 648, between Moengo Tapoe and Grote Zwiebelzwamp; shrub, $3 \mathrm{~m}$ high, diam. $3 \mathrm{~cm}$ ); Uw 1319 (Lanjouw \& Lindeman 755, between Moengo Rapoe and Grote Zwiebelzwamp; diam. $3.5 \mathrm{~cm}$ ); Uw 1321 (Lanjouw \& Lindeman 785, between Moengo Tapoe and Grote Zwiebelzwamp; treelet, $4 \mathrm{~m}$ high, diam. $3 \mathrm{~cm}$ ); Uw 1324 (Lanjouw \& Lindeman 801, between Moengo Tapoe and Grote Zwiebelzwamp; tree, $8 \mathrm{~m}$ high, diam. $5.5 \mathrm{~cm}$ ).

Ixora orinocensis Spruce: Suriname - Uw 2557 (Maguire 24413 = Yale 44123, Tafelberg; tree, $10 \mathrm{~m}$ high, diam. $10 \mathrm{~cm}$ ); Uw 2558 (Maguire 24282 = Yale 44110, Tafelberg; tree, $8 \mathrm{~m}$ high, diam. $10 \mathrm{~cm}$ ).

Ixora surinamensis Brem.: Suriname - Uw 3397 (Lindeman 4985, Mapane Kreek area; treelet, $3.5 \mathrm{~m}$ high, diam. $2 \mathrm{~cm}$ ); Uw 3399 (Lindeman 4992, Mapane Kreek area; treelet, diam. $1.5 \mathrm{~cm}$ ); Uw 3219 (Lindeman 4677, Mapane Kreek area; tree, $6 \mathrm{~m}$ high, diam. $5 \mathrm{~cm}$ ); Uw 3408 (Lindeman 5012, Mapane Kreek area; treelet, $5 \mathrm{~m}$ high, diam. $3 \mathrm{~cm}$ ); Uw 4390 (Lindeman 6404, Upper Coppename R.; treelet, $3 \mathrm{~m}$ high, diam. $2 \mathrm{~cm}$ ).

Malanea duckei Standley: Venezuela - Uw 12434 (Williams 16009, Sanariapo).

Malanea macrophylla Bartl. ex Griseb. : Suriname - Uw 12025 (v.Donselaar 3199, Brokopondo; diam. $6 \mathrm{~cm}$ ).

Mapouria chionantha Muell. Arg.: Suriname - Uw 1351 (Lanjouw \& Lindeman 960, between Moengo Tapoe and Grote Zwiebelzwamp; diam. $6 \mathrm{~cm}$ ); Uw 2741 (Lindeman 3753, Surin. R., Jodensavanne; $6 \mathrm{~m}$ high, diam. $4.5 \mathrm{~cm}$ ); Uw 3233 (Lindeman 4699, Suriname R., Jodensavanne; $7 \mathrm{~m}$ high, diam. $5 \mathrm{~cm}$ ); Uw 3775 (Lindeman 5437, Perica R., treelet, $7 \mathrm{~m}$ high, diam. $5 \mathrm{~cm}$ ); Uw 12032 (v. Donselaar 3209, Brokopondo; treelet, diam. $2.5 \mathrm{~cm}$ ).

Mapouria chlorantha (Bth.) Brem.: Suriname - Uw 2867 (Lindeman 3892, Mapane Kreek area; tree, $9 \mathrm{~m}$ high, diam. $6 \mathrm{~cm}$ ); Uw 3029 (Lindeman 4059, Mapane Kreek area; tree, $11 \mathrm{~m}$ high, diam. $5 \mathrm{~cm}$ ); Uw 3099 (Lindeman 4140, Suriname R., Jodensavanne; tree, $12 \mathrm{~m}$ high, diam. $9.5 \mathrm{~cm}$ ); Uw 4626 (Lindeman 6845, Mapane Kreek area; diam. $9 \mathrm{~cm}$ ); Uw 4933 (Schulz 7200, Mapane Kreek area; diam. $20 \mathrm{~cm}$ ); Uw 6749 (Heyligers 720, Suriname R., Jodensavanne; tree, $6.4 \mathrm{~m}$ high, diam. $6 \mathrm{~cm}$ ).

Mapouria fockeana (Miq.) Brem.: Suriname - Uw 3823 (Lindeman 5526, Coppename R.; treelet, $5 \mathrm{~m}$ high, diam. $3 \mathrm{~cm}$ ).

Mapouria opaca Brem.: Suriname - Uw 1962 (Lanjouw \& Lindeman 2874, Nassau Mountains; tree, $7 \mathrm{~m}$ high, diam. $7 \mathrm{~cm}$ ); Uw 3965 (Lindeman 5811, Rikanau near Moengo; tree, 5.5m. high, diam. $4.5 \mathrm{~cm}$ ); Brazil - Uw 9124 (Belem 51926, Rio Araguari). 
Morinda citrifolia L.: Suriname - Uw 3106 (Lindeman 4167, Paramaribo; treelet, $3 \mathrm{~m}$ high, diam. $1.5 \mathrm{~cm}$ ); Sandwich Islands - Uw 12435 (Hawaiian Hist. Soc. 275253).

Naletonia violacea (Aubl.) Brem.: Suriname - Uw 8531 (Daniels \& Jonker 760, Emmaketen; shrub, $3 \mathrm{~m}$ high, diam. $4 \mathrm{~cm}$ ).

Pagamea capitata Bth.: Suriname - Uw 2560 (Maguire 24740 = Yale 44238, Tafelberg; shrub, $5 \mathrm{~m}$ high, diam. $10 \mathrm{~cm}$ ); British Guiana - Uw 1085 (Forest Dept. 2375, Mahaicony R.; shrub, diam. $3.5 \mathrm{~cm}$ ).

Pagamea guianensis Aubl.: Suriname - Uw 355 (Stahel 355, Wayombo); Uw 2867a (Lindeman 3893, Suriname R., Jodensavanne; tree, $13 \mathrm{~m}$ high, diam. $8 \mathrm{~cm}$ ); Uw 2884 (Lindeman 3912, Mapane Kreek area; tree, $13 \mathrm{~m}$ high, diam. $5 \mathrm{~cm}$ ); Uw 2893 (Lindeman 3920, Mapane Kreek area; tree, $8 \mathrm{~m}$ high, diam. $7 \mathrm{~cm}$ ); Uw 3613 (Lindeman 4908, Mapane Kreek area; tree, $13 \mathrm{~m}$ high, diam. $7.5 \mathrm{~cm}$ ); Uw 6752 (Heyligers 724, Suriname R.; tree, $7.5 \mathrm{~m}$ high, diam. $2 \mathrm{~cm}$ ); British Guiana - Uw 1084 (Forest Dept. 5237, Demerara R.; shrub, $2 \mathrm{~m}$ high, diam. unknown, over $5 \mathrm{~cm}$ ); Brazil - Uw 8164 (Krukoff 7083. Amazonas; tree, $15 \mathrm{~m}$ high, over $12 \mathrm{~cm}$ ).

Palicourea crocea (Sw.) DC.: Suriname - Uw 1481 (Lanjouw \& Lindeman 1408, Coppename R.; shrub, $3 \mathrm{~m}$ high, diam. $2 \mathrm{~cm}$ ); Venezuela - Uw 10988 Breteler 3115, near Merida; treelet, $10 \mathrm{~m}$ high, diam. $4 \mathrm{~cm}$ ).

Palicourea guianensis Aubl.: Suriname - Uw 231 (Stahel 231, Zanderij I); Uw 626 (BBS 28, Suriname R., Suhoza); Uw 1360 (Lanjouw \& Lindeman 977, Moengo Tapoe; tree, $11 \mathrm{~m}$ high, diam. $11 \mathrm{~cm}$ ); Uw 1541 (Lanjouw \& Lindeman 1747, Tibitisavanne; tree, $8 \mathrm{~m}$ high, diam. $8.5 \mathrm{~cm}$ ); Uw 1925 (Lanjouw \& Lindeman 2782, Nassau Mountains; treelet, $6 \mathrm{~m}$ high, diam. $6.5 \mathrm{~cm}$ ); Uw 2029 (J.\& P.A.Florschütz 1355, Saramakka R.; $15 \mathrm{~m}$ high, diam. $8.5 \mathrm{~cm}$ ); Uw 2561 (Maguire 23762 = Yale 44061, Saramakka R.; tree, $12 \mathrm{~m}$ high, diam. $15 \mathrm{~cm}$ ); Uw 11711 (LBB 11008 (Maas), Nickerie R.; tree, $15 \mathrm{~m}$ high, diam. $20 \mathrm{~cm}$ ); British Guiana - Uw 1086 (Forest Dept. 2015); Uw 4860 (Cowan 39340; diam. 4 cm); French Guiana - Uw 5363 (BAFOG $288 \mathrm{M}$ ).

Palicourea longiflora (Aubl.) A. Rich.: Suriname - Uw 1657 (Lanjouw \& Lindeman 2209, Nassau Mountains; shrub, $3 \mathrm{~m}$ high, diam. $2 \mathrm{~cm}$ ); Uw 4550a (Lindeman 6731a, Mapane Kreek area; $3 \mathrm{~m}$ high, diam. $12 \mathrm{~cm}$ ).

Posoqueria gracilis Rudge: Suriname - Uw 1919 (Lanjouw \& Lindeman 2774, Nassau Mountains; treelet, $5 \mathrm{~m}$ high, diam. $5 \mathrm{~cm}$ ).

Posoqueria latifolia (Rudge) R. \& S.: Suriname - Uw 298 (Stahel 298, Zanderij I); Uw 1275 (Lanjouw \& Lindeman 600, Moengo Tapoe; diam. $8 \mathrm{~cm}$ ); Uw 1327 (Lanjouw \& Lindeman 806, Moengo Tapoe; diam. $5 \mathrm{~cm}$ ); Uw 1664 (Lanjouw \& Lindeman 2227, Nassau Mountains; diam. $4.5 \mathrm{~cm}$ ); British Guiana - Uw 1087 (Forest Dept. 3340); Brazil - Uw 6365 (Reitz 14908, Santa Catarina; tree, $8 \mathrm{~m}$ high, diam. $4.5 \mathrm{~cm}$ ).

Posoqueria longiflora Aubl.: Suriname - Uw 4294 (Lindeman 6275, Coppename R.; shrub, 4.5 high, diam. $4.5 \mathrm{~cm}$ ); Uw 10104 (Schulz 9631 ; diam. $6 \mathrm{~cm}$ ).

Psychotria paniculata (Aubl.) Raeusch: Suriname - Uw 1632 (Lanjouw \& Lindeman 2159, Nassau Mountains; treelet, $8.5 \mathrm{~m}$ high, diam. $6 \mathrm{~cm}$ ); British Guiana - Uw 1089 (Forest Dept. 5305).

Randia spinosa (Jacq.) Karsten: Suriname - Uw 1656 (Lanjouw \& Lindeman 2206, Marowijne R.; diam. $4 \mathrm{~cm}$ ); Uw 3820 (Lindeman 5523, Coppename R.; tree, $11 \mathrm{~m}$ high, diam. 10 $\mathrm{cm}$ ); Uw 11098 (Florschütz \& Maas 2795,Coppename R.; treelet, $3 \mathrm{~m}$ high, diam. $3 \mathrm{~cm}$ ); Uw 10624 (Schulz 10008a, Zuid R.; treelet, $8 \mathrm{~m}$ high, diam. $5 \mathrm{~cm}$ ).

Retiniphyllum laxiflorum (Bth.) N.E. Brown: Suriname - Uw 2554 (Maguire 24786 = Yale 44245, Tafelberg; shrub, $3 \mathrm{~m}$ high, diam. $1 \mathrm{~cm}$ ).

Retiniphyllum schomburgkii (Bth.) Muell. Arg.: Suriname - Uw 2555 (Maguire $24788=$ Yale 44247, Tafelberg; shrub, $3 \mathrm{~m}$ high, diam. $3 \mathrm{~cm}$ ); Uw 2598 (Maguire $24787=$ Yale 44246, Tafelberg; shrub, $3 \mathrm{~m}$ high, diam. $3 \mathrm{~cm}$ ).

Ronabea latifolia Aubl.: Suriname - Uw 1888 (Lanjouw \& Lindeman 2713, Nassau Mountains; diam. $3.5 \mathrm{~cm}$ ).

Rosenbergiodendron formosum (Jacq.) Fagerl.: Suriname - Uw 1461 (Lanjouw \& Lindeman 1365, Coppename R.; shrub, $2.5 \mathrm{~m}$ high, diam. $2.5 \mathrm{~cm}$ ); Uw 4279 (Lindeman 6238, 
Moengo Tapoe; diam. $8 \mathrm{~cm}$ ); Uw 10926 (Florschütz \& Maas 2331, Kabalebo air strip; diam. $4 \mathrm{~cm})$.

Rudgea cornigera Brem.: Suriname - Uw 3283 (Lindeman 4790, Mapane Kreek area; treelet, $4 \mathrm{~m}$ high, diam. $4 \mathrm{~cm}$ ); Uw 4417 (Lindeman 6437, Coppename R.; treelet, $5 \mathrm{~m}$ high, diam. $3.5 \mathrm{~cm})$.

Rudgea gracilifora Hansley: Suriname - Uw 4701 (Lindeman 6986, Nassau Mountains; treelet, $6 \mathrm{~m}$ high, diam. $5 \mathrm{~cm}$ ).

Rudgea hostmanniana Bth.: Suriname - Uw 2787 (Lindeman 3805, Suriname R., Jodensavanne; treelet, $6 \mathrm{~m}$ high, diam. $5 \mathrm{~cm}$ ); Uw 3184 (Lindeman 4589, Rijnsdijkseweg, $25 \mathrm{~km} \mathrm{S.} \mathrm{of}$ Paramaribo; $7 \mathrm{~m}$ high, diam. $6.5 \mathrm{~cm}$ ); Uw 4517 (Lindeman 6667, Corantijne R.; tree, $5 \mathrm{~m}$ high, diam. $4.5 \mathrm{~cm}$ ).

Schradera rotundata Standley: Colombia - Uw 12437 (Cuatrecasas 15755).

Sickingia fragrans (Rusby) Standley: Peru - Uw 12438 (Williams 6660, Tarapoto).

Sickingia glazovii K. Schum.: Brazil - Uw 12345 (Ministerio de Agricultura Serviço FlorestalSeçao de Technologia 3894).

Sickingia maxonii Standley: Panama - Uw 7134 (Herb.: U.S. Nat. Herb.; Smithsonian Institution 663).

Sickingia oliveri K. Schum.: Brazil - Uw 12346 (Ministerio de Agricultura Serviço FlorestalSeçao de Technologia 664).

Sickingia sampaioana Standley: Brazil - Uw 6921 (Reitz 16470, Santa Catarina; diam. $3.5 \mathrm{~cm}$ ).

Simira rubescens (Bth.) Brem.: Peru - Uw 8711 (Ellenberg 2509, El Sacramento; tree, 10 m high, diam. $10 \mathrm{~cm})$.

Strempelia cornifolia (H. \& B.) Brem.: Suriname - Uw 10107 (Schulz 9634; diam. $2.5 \mathrm{~cm}$ ).

Uncaria guianensis (Aubl.) Gmel.: Suriname - Uw 2550 (Maguire $23807=$ Yale 44063, Saramakka R.; liana, diam. $6 \mathrm{~cm}$ ); Uw 3834 (Lindeman 5543, Coppename R.; liana, diam. $2 \mathrm{~cm}$ ); Uw 6847 (Schulz 8454, Suriname R., Jodensavanne; liana, diam. $2.5 \mathrm{~cm}$ ).

Warszewiczia coccinea (Vahl) Klotzsch: Venezuela - Uw 11841 (Breteler 4043, between Barinas and San Cristóbal; tree, $9 \mathrm{~m}$ high, diam. $11 \mathrm{~cm}$ ).

\section{ACKNOWLEDGEMENTS}

The author wishes to thank Dr. Alberta M. W. Mennega for her help and encouragement during the investigation. Besides, the author is greatly indebted to Mr. P. van der Kruk and Dr. K. U. Kramer for correcting the English text.

\section{REFERENCES}

(see also the references of the preceding paper in Act. Bot. Neerl. 18 (1), 1969),

Bentham, G. \& W. J. Hooker. (1873): Genera Plantarum II (7). London.

Bremekamp, C. E. B. (1934): Notes on the Rubiaceae of Suriname. Rec. Trav. Bot. Néerl. 31 : 248-308.

- (1932): Rubiaceae; in A. Pulle, Flora of Suriname IV (1): 113-298. Amsterdam.

- (1940): On Urophyllum Wall. (Rubiaceae) and its nearest allies. Rec. Trav. Bot. Néerl. 37: 171-197.

- (1954): The identity of Simira tinctoria Aubl. Acta Bot. Neerl. 3: 150-153.

- (1956): On the position of Platycarpum Humb. \& Bonpl., Henriquezia Spr. ex Bth, and Gleasonia Standl. Acta Bot. Neerl. 6: 351-357.

- (1959): A species of Antirrhea (Rubiaceae) from Suriname. Acta Bot. Neerl. 8: 479-481.

DuCKe, A. (1922): Arch. Jard. Bot. Rio de Janeiro 3: 255-256.

Hess, R. W. (1936): Occurrence of raphides in wood. Trop. Woods. 46: 22-31.

KoEK-Noorman, J. (1969): A contribution to the wood anatomy of South American (chiefly Suriname) Rubiaceae. I. Acta Bot. Neerl. 18: 108-123.

NoRmand, D. (1960): Atlas des bois de la côte d'Ivoire. Nogent-sur-Marne. 